\title{
Örgütsel Sessizlik ile Kişilik ve Yaşam Doyumu Etkileşimi: Kamu Sektöründe Bir Araştırma
}

\author{
The Interactions of Organizational Silence with Personality and Life Satisfaction: \\ A Research on Public Sector
}

\section{Dr. Eylem Şimşek - Yrd. Doç. Dr. Hakkı Aktaş}

\section{Öz}

Bu çalışmanın amacı, örgütsel sessizlik, kişilik ve yaşam doyumu arasındaki etkileşimi araştırmaktır. Nicel paradigma temelinde, betimsel araştırma modeli, ilişkisel model ve karşılaştırmalı modeli içeren karma yaklaşım kullanılmıştır. İstanbul'da bir kamu işletmesi ve bir kamu üniversitesinde çalışan 185 katıllmoıcıdan veri toplanmıştır. Veriler korelâsyon, varyans ve regresyon analizi yöntemleriyle incelenmiştir. Analiz sonuçlarına göre kabullenici ve savunmacı sessizlik arttıkça yaşam doyumu azalmaktadır. Savunmacı sessizlik yaşam doyumundaki varyansin \%3.4’ünü açıklamaktadır. Kişilik özellikleri dikkate alındığında, kabullenici sessizlik, dışadönüklük (\%17.8) ve yeniliklere açıklı (\%2.6) tarafından; savunmacı sessizlik dı̧̧adönüklük (\%3.7) tarafindan ve ilişkisel sessizlik sorumluluk (\%4.8) ve yeniliklere açılılk (\%2.6) tarafindan yordanmaktadır. İçedönüklerin daha çok kabullenici ve savunmacı sessizlik gösterme, sorumlu ve yeniliklere açık olanların ise daha çok ilişkisel sessizlik gösterme eğilimleri olduğu belirlenmiştir. İlişkisel sessizlik savunmacı ve kabullenici sessizliğe kiyasla daha olumlu kişilik özellikleriyle özdeşleşmektedir. Savunmacı sessizliğin yaşam doyumundaki belirleyici rolü sessizliğin yalnızca kurumsal bir sorun olmadığını, bireyin tüm yașamını olumsuz etkilediğini göstermektedir.

Anahtar Sözcükler: Örgütsel Sessizlik, Kişilik, Yaşam Doyumu, Mutluluk

\begin{abstract}
The purpose of this research is to explore the interaction of organizational silence with personality and life satisfaction. The quantitative paradigm, including descriptive, relational, and comparative models was employed. Data were collected from 185 participants in a public university and in a public enterprise in Istanbul. Data were analyzed by correlation analysis, analysis of variance, and multi regression techniques. The findings pointed out that as acquiscent and defensive silence increased, life satisfaction significantly decreased. Defensive silence explained 3.4\% of the variance on life satisfaction. When focused on personality, acquiscent silence was predicted by extraversion (17.8\%) and openness to experience (2.6\%). Defensive silence was predicted by extraversion (3.7\%). Pro-social silence was predicted by conscientiousness (4.8\%) and openness to experience (2.6\%). Introverts were more likely to experienc eacquiscent and defensive silence. Whereas those who have higher scores on conscientiousness and openness to experience show most probably prosocial silence. Prosocial silence was associated with more positively personality characters compared to acquiscent and defensive silence. The predictive role of defensive silence on life satisfaction stressed that silence was not only an organizational problem but also a problem affecting the whole life of the individuals in a negative way.
\end{abstract}

Keywords: Organizational Silence, Personality, Life Satisfaction, Happiness

Dr. Eylem Şimşek, Hava Kuvvetleri Komutanlığı, ekocarslan@yahoo.com

Yrd. Doç. Dr. Hakkı Aktaş, Bahçeşehir Üniversitesi Sağlık Bilimleri Fakültesi, hakki.aktas@bahcesehir.edu.tr 


\section{Giriş}

Yönetim süreçlerinin her safhasında işgörenlerin katılımının örgütsel pek çok değişkenle olumlu ilişki içerisinde olduğu Hawtorne ve Harwood araştırmalarından beri bilinen bir olgudur. Japon şirketlerinin başarısına ilişkin araştırma sonuçları, bu şirketlerde bireylerin yalnızca örgütsel vatandaşlar olarak görülmediğini göstermiştir. Japonlardan esinlenen $\mathrm{Z}$ tipi yönetim anlayışında aile, kültür, gelenekler ve sosyal ilişkiler dikkate alınarak bireyin tüm yaşamı bütün olarak düşünülmekte ve buna göre davranılmaktadır (Sharma, 2013). Bireyin iş yaşamı ve iş dışındaki yaşamı arasında keskin sınırlar olmadığına ve birbiriyle etkileştiğine ilişkin söz konusu yaklaşımlar (Keser, 2005 ) örgütsel değiş̧kenlerin örgüte olduğu kadar bireyin tüm yaşamına etkisini de sorgulamayı zorunlu hale getirmiştir.

Bu çalışmada örgütsel sessizlik, kişilik ve yaşam doyumu arasındaki etkileşimin incelenmesi amaçlanmıştır. Örgütsel sessizlik, örgütsel iletişimin aksayan bir yönü olarak ortaya çıkmaktadır (Beheshtifar, Borhani ve Moghadam, 2012). Herhangi bir değişiklik yaratamama düşüncesi, öz yeterliliğin düşük olması, korku, kendini risk altında hissetme ve savunma, kendini korumak için doğru bildiklerinden vazgeçme, örgütsel sessizliğin altında yatan düşünce, tutum ve davranışı kapsayan temel olumsuz motiflerdir (Dyne, Ang ve Botero, 2003). Örgütsel sessizliğin huzursuzluk, gerginlik, stres, aşağılanma hissi yarattığı belirlenmiştir (Çakıcı, 2007; Perlow ve Williams, 2003). Bu duygular çoğunlukla mutsuzlukla eşleştirilmektedir.

Bireyin mutluluğu eşdeyişle yaşam doyumunda hem bireysel özelliklerinin (Schimmack, Oishi, Furr ve Funder, 2004) hem de örgütsel dinamiklerin ve değişkenlerin rolü vardır (Keser, 2005). Bireyin yaşam doyumun artmasında, iş doyumu (Uyguç vd., 1998), iletişim doyumu (Şimşek, 2011), bağllık (Seligman, 2007, s.146-147), örgütsel destek (Dixon ve Sagaz, 2007) gibi örgütsel deneyimlerin etkili olduğu belirlenmiştir. Ancak örgütsel sessizliğin yaşam doyumuna etkisine yönelik alanyazında bir çalışmaya rastlanılmamıştır. Bu etkileşimde kişiliğin de dikkate alınması, örgütsel sessizliğin yaşam doyumuyla ilişkisinde bireysel farklılıkların sorgulanması açısından önemlidir.

Bireyi baskılayıcı yapıdaki örgütsel sessizliğin bireyin yaşam doyumu ve mutluluğuna olan etkisinin ortaya konulması, örgütsel sessizlik sorununun olumlu psikoloji yaklaşımıyla incelenmesini sağlayacaktır. Örgütsel sessizliğin yalnızca kurumsal bir sorun olup olmadığı, bireyin tüm yaşamına ilişkin değerlendirmelerinde de olumsuzluklara yol açıp açmadığının belirlenmesi, örgütsel sessizlik konusunun daha geniş bir çerçevede aydınlatılması ve soruna ilişkin yeni çözüm yollarının önerilmesi açısından önemlidir.

\section{Literatür Taraması}

\section{Örgütsel Sessizlik}

Örgütsel sessizlik alanyazını örgütsel sessizliğin tanımı ve yapısı, nedenleri ve sonuçları üzerine yapılanmıştır. Örgütsel sessizlik, bireylerin işlerini ve örgütlerini iyileştirmeyle ilgili devinsel, bilişsel ve duyuşsal gerçek fikirlerini, değişim yapabileceği düşünülen bireylerden kasitlı olarak esirgemeleridir (Pinder ve Harlos, 2001, s.334).Örgütsel sessizlik organizasyon açısından önemli bir durum karşısında gerekli tepkiyi göstermeme, çok az ya da hiçbir şey söylememe tutumudur (Henriksenve Dayton, 2006). Pinder ve Harlos’a göre (2001) bir sessizlik durumunun örgütsel sessizlik olgusu olarak kavramsallaştırılması için bireyin kasıtlı, aktif ve amaçlı olarak mı sessiz kaldığına dikkat edilmesi gerekmektedir.

Dyne, Ang ve Botero (2003) örgütsel sessizliğin çok boyutlu yapıda olduğunu vurgulamaktadır. Bireylerin örgütle ilgili düşüncelerini ya da bilgilerini açıklamama güdüleri, kabullenme, korku/savunma ve ilişkileri koruma olarak sınıflandırılmış ve kabullenici, savunmacı ve korumacı sessizlik olarak modellenmiştir. Thomson ve Bunderson (2003) faydacı sessizlik kavramını da bu sinıflandırmaya eklemektedir. Kabullenici sessizlik, hiçbir şeyin değişmeyeceği inancıyla var olan durumu benimseme anlayışına dayanmaktadır. "Böyle gelmiş, böyle gider...", "boşver çeneni yorma..." gibi söylemlerin içine gizlenmiştir. Savunmacı sessizlik, zor durumda kalmamak, konuşmanın olası kötü sonuçlarından kaçmak için sessiz kalmadır. Savunmacı sessizlik, bireyin yarar-zarar analizi yapması ve konuşmanın zararının çok olacağına karar vermesidir. İlişkisel sessizlik ise çoğunlukla örgüt yararına yapılan, örgüt içindeki ilişkilerin korunması için sessiz kalınmasıdır (Çakıcı, 2010, s.32).

Örgütlerde açık, kendini ifade edebilen, sorunlara çözüm bulabilen, takım çalışmasına yatkın yaratıcı bireylerin olması idealize edilmesine ve bu özelliklerin 
geleceğin istihdam becerileri olarak belirlenmesine rağmen (ACCI/BCA, 2002) örgütsel sessizlik günümüzde sıklıkla karşılaşılan bir sorun olarak ortaya çıkmaktadır. Bienefeld ve Grote (2011) havacılık sektöründeki yaptıkları çalışmada 1751 uçuş mürettebatının karşılaştıkları olayların yarısında sessiz kaldıklarını belirlemiştir. Sessizlik alt kademede en yüksek düzeydedir. En az sessizlik kaptan pilotlarda görülmektedir. Roberts ve O’Reilly (1974) bireylerin özellikle üstleriyle iletişimlerinde olumsuz içerikli bilgiyi iletmekten ya kaçındığı ya da bilginin olumsuzluk niteliğini azaltma yoluna gittiğini belirtmektedir.

Kurum için yararlı olacak bilgiyi gizlemek olan örgütsel sessizliğin organizasyona olan zararları açıktır. 2003 yilındaki Colombia Uzay Mekiği faciasına neden olan hata aslında zamanında mühendisler tarafindan farkedilmiştir. Ancak, kurumda yöneticilere duymak istemedikleri şeylerin söylenmesinden korkulan bir kültür yapısı oluşmuştur. Buna ilave olarak, kurumdaki bütçe kısıtlamaları zorlayıcı hale gelmiştir. Görev yöneticisi ekibe yüksek maliyet gerektiren düzeltici işlem isteyip istemediklerini sorduğunda kimse konuşmamış, yanıt vermemiştir. Böylece, sorunun incelenmeden bir kenara birakilması mekiğin patlamasıyla bir trajediye dönüşmüştür (VitalSmarts,2005).

Sağlık sektöründe 1700 hemşire, doktor, klinik bakım personeli ve yöneticilerle yapılan başka bir çalışmada doktorların \%88'inin klinik açıdan yanlış karar veren meslektaşlarıyla çalıştıklarını ifade ettikleri belirlenmiştir. Sağlık çalışanlarının yarısından fazlası kuralların çiğnendiğini, yetersizlik gösterildiğini, zayıf performans ve takım çalışması gösterildiğini, bu kişilere güven ve saygı duymadıklarını ifade etmiştir. Ancak, çalışanlardan yalnızca \%10'undan daha azının bu konudaki kaygılarını dile getirmeleri sağlık sektöründeki sessizliğin kritik boyutunu göstermektedir. Mesleğin doğası gereği önemli durumlarda çabuk karar alma gerekliliğ̣i, açık tartışmalar yapılamaması, eğitim ve güç yapısındaki farklılıklar sessizlik tutumunu tetiklemektedir (VitalSmarts,2005)

Örgütsel sessizliğe yol açan temel nedenler bireysel, sosyal ve organizasyonel etmenler olarak siniflanmaktadır. Bireysel etmenler kısa yol kullanma, önyargılar ve mevcut statükoyu sürdürmek, var olan durumu olduğu gibi korumak (status quo) gibi düşüncelerdir. Sosyal etmenler, güvensizlik iklimi ve uyma davranışı ile sorumluluk konusundaki belirsiz- liklerdir. Örgütsel etmenler ise tartışmasız inançlar, gereksiz ve doğru olmayan bilgiler ve işle ilgili diğer birimlerle bağımlılıkların ihmal edilmesidir (Henriksen ve Dayton, 2006).

Örgütle ilgili önemli konulara katılmama ve geri çekilme davranışı, örgütsel iletişimin olumsuz ya da sağlıksız gerçekleşen biçimidir. Eşdeyişle örgütsel sessizlik bir iletişim sorunu olarak değerlendirilmektedir (Pinder veHarlos, 2001: 345-346). Örgütsel iletişimin hiyerarşik yapıya bağlı biçimsel (yönetsel, formal) ve çalışanların psikolojik ve toplumsal gereksinimleri doğrultusunda biçimsel olmayan (psiko-sosyal, informal) yönleri vardır (Gürüz veEğinli, 2008: 178). Bu bağlamda örgütsel sessizlik bireysel, yönetsel, sosyal açıdan bazı sorunlara işaret etmektedir.

Bireylerin sessiz kalmasındaki temel etmenler; konuşmanın bir şey değiştirmeyeceği ve amirlerinin tepki göstermeyeceği düşüncesi, özyeterliliklerinin düşük olması, cezalandırılma korkusu, olumsuz değerlendirilmek, diğer bireyleri koruma kaygısı, sorun çıkaran şikâyetçi durumuna düşmeme iste, mevcut ilişkileri bozmama ya da iş ve yükselme olanaklarını kaybetmeme arzusu ve yöneticilerinin destekleyici ve ulaşılabilir olmaması şeklinde sıralanmıștır. Sessiz kalınan konular, başta iş arkadaşları ile yöneticilerini performansı ve yeterliliği olmak üzere örgütsel süreçler, ücret ve ücret eşitliğidir (Dyne vd., 2003; Milliken vd., 2003).

Örgütsel sessizliğin kurumsal nedenlerinden en önemlileri iletişim olanakları ve üst yönetimin tutumlarıdır (Vokala ve Bourades, 2005). Örgütsel sessizlik genellikle üstlerle olan ilişkilerde ortaya çıkmaktadır. "Kral çıplak" hikâyesi hiyerarşik yapıdaki örgütsel sessizlik durumunu betimlemek açısından önemli bir örnektir (Morrison ve Milliken, 2010). Bireyler üstleriyle iyi ilişkileri olmasını istemekte, bu ilişkilerin bozulmaması için sessiz kalabilmektedir. Üstlerin liderlik davranışı, örgütsel sessizliğin karşıtı kabul edilen konuşma davranışının en önemli belirleyicilerindendir (Detert ve Borris, 2007). Üst yönetime güven ve üst yönetimin açıklı̆̆ sessizlik davranışını azaltmaktadır (Premeaux ve Bedeion, 2003). Amirlerin destekleyici, yargılamayan, iletişime açık bir tutum içinde olması ve kurum kültürünün bu doğrultuda gelişmesi sessizlik davranışını otomatik olarak azaltmaktadır. 
Örgütsel sessizliğin sonuçlarının da nedenleri gibi çoklu bir yapıda değerlendirilmesi gerektiği düşünülmektedir. Örgütsel sessizliğin sonuçları örgütsel ve bireysel boyutta incelenebilir. Örgütsel sessizlik, kalitesiz bir iletişim iklimi (Vakola ve Boudaras, 2005), düşük performans (Aktaş ve Şimşek, 2013), düşük motivasyon, örgütsel öğrenme ile yüksek işten ayrılma ve sabotaj davranışları (Morrison ve Milliken, 2009), düşük bağlllık ve düşük örgütsel güven (Nikolau, Vakolave Bourantas, 2011), yetersiz işdoyumu (Aktaş ve Şimşek, 2012; Barçın, 2012) gibi örgütsel değişkenlerle ilişkilidir.

Örgütsel sessizlik bireyi de etkilemekte ve yaşamında sorunlara yol açabilmektedir. Konuşmak birey açısından pek çok risk taşısa da konuşmamak ya da konuşamamak birey açısından yıpratıcıdır. Birey konuşamadığında kendisini çaresiz hissetmektedir (Milliken ve Morrison, 2003). Örgütsel sessizlik bireyde endişe ve strese neden olabilmektedir (Morrison ve Milliken, 2000).Örgütsel sessizliğin bireyde oluşturduğu rahatsızlıkların tükenmişlik olarak ortaya çıktığı belirlenmiştir (Aktaş ve Şimşek, 2012; Tahmasebi, Sobhanipour ve Aghaziarati, 2013).

Örgütsel sessizlik yaratıcılığa da zarar vermektedir (Pentilla, 2003). Alternatif bakış açılarının geliştirilmesine ket vurmakta, katılımcilığ verme becerilerine zarar vermektedir (Huang, Van de Vliert ve Van der Vegt, 2005). Örgütsel sessizlik ayrıca bireyde gücenme ve değersizlik duygularını uyandırmaktadır (Çakıcı, 2007; Perlow ve Williams, 2003). Kontrol duygusunun ortadan kalkmasiyla stres ve huzursuzluk hissetmekte, içine düşülen çelişkili duruma bağlı olarak gerginlik hissedilmektedir (Alparslan ve Kayalar, 2012; Ehtiyar ve Yanardağ, 2008). Örgütsel sessizliğin bireyin mutluluğunu nasıl ve ne ölçüde etkileyebildiği sorgulanması gereken bir konudur.

\section{Yaşam Doyumu ve Örgütsel Sessizlik}

Yaşam doyumu, mutluluk ve yaşam kalitesi gibi kavramlar hümanistik psikoloji kökenli olumlu psikoloji paradigmasının 2000'li yıllarda şekillenmesiyle önem kazanmıştır. Olumlu psikoloji paradigması bireyin mutluluğuna ilişkin çalışmaların, kuramların oldukça az olduğuna dayanmaktadır (Seligman vd., 2005). Olumlu psikolojide odak noktası, hasta ya da normal dışı olarak tanımlanmayan ve toplumun büyük çoğunluğu oluşturan normal bireylerin mutluluğun, iyi oluş halinin artırılmasına ilişkin yöntem ve kuramların geliştirilmesidir.Olumlu psikolojinin söylemleri kısa zamanda diğer alanlara da yayılmış ve olumlu örgütsel iletişim kavramı (Şimşek, 2011) ortaya çıkmıştır. Olumlu örgütsel iletişim, örgüt içindeki iletişim çabalarının bireyin psikolojik, teknik ve sosyal gereksinimlerini dikkate alacak şekilde düzenlenmesi anlayışına dayanmaktadır.

Yaşam doyumu, bireyin yaşamını nasıl değerlendirdiği ya da yaşamının ne kadar iyi olduğuna ilişkin bilişsel değerlendirmesi olup; genel yaşam doyumu (Diener vd., 1985) ve yaşam alanlarındaki doyum ile ölçülmektedir. Yaşam doyumu tümdengelimci bir yaklaşımla, daha çok kişilik gibi etmenlere bağlı olarak yaşamın genel değerlendirmesidir. Yaşam alanlarındaki doyum ise tümevarımcı bir yöntemle, iş, aile, sağlık vb. gibi farklı alanların toplamı olarak iyi olmayı açıklamaktadır (Şimşek, 2011). Bu çalışmada her iki yaklaşıma ilişkin ölçümler ve değerlendirmeler yapılmaktadır.

Örgütlerdeki pek çok aksaklığın kaynağının da, çözümünün de örgütlerdeki iletişim uygulamaları/ kullanılan iletişim teknikleri olduğu bilinmektedir. Bireylerin iş yaşamlarından memnun olup olmadığına ilişkin olarak genellikle iş doyumu ölçülmektedir. Örgütsel iletişim ile yaşam doyumu arasındaki korelasyon, iş doyumu ile yaşam doyumu arasındaki korelâsyondan yüksektir. Örgütsel iletişim, yaşam doyumundaki varyansın \%18'ini açılamakta olup kişilik ve demografik verilerin yaşam doyumunda açıladığı varyansın çok üzerindedir (Şimşek, 2011). $\mathrm{Bu}$ durum örgütsel iletişim uygulamalarının bireylerin mutluluğundaki önemini açıklamaktadır.

Örgütsel sessizlik ise örgütsel iletişim sürecinin sağlıklı işlemediği bir süreci temsil etmektedir. Örgüt yaşamındaki pek çok sorun örgütsel sessizlik ile pekişmekte ve gelecekte daha büyük sorunlarla kendisini göstermektedir. Bireylerin bilerek sessiz kalması, çoğunlukla bireysel, ahlaki, etik ve yasal bazı standartları ihlal etmesi demektir (Knoll ve vanDick, 2013). Bireyin sessizlikle ortaya çıan engellenme hissi ve düşüncelerini ifade edememesi, kendini gerçekleştirmeye, ilerlemeye, potansiyelini ortaya çıkarmaya yönelik yaşam doyumu felsefesine tezattır.

Örgütsel sessizlik, biliş ve davranış arasındaki uyumsuzluk olup bireyde gerginlik yaratmaktadır. Her ne kadar kendini ve diğer insanları korumak için sessiz 
kalınmış olsa da sessizlik davranışının kendisi rahatsızlık unsurudur. Sessizlik aşağılanma, korku, stres, ilişkilerin yozlaşması, yaratıcılığın ve verimliliğin azalması hislerini yaratmaktadır (Cortina ve Magley, 2003; Perlow ve Williams, 2003). Örgütsel sessizlik öğrenmeyi de olumsuz etkilemektedir (Morrison ve Milliken, 2003).

İstemli bir davranış olan örgütsel sessizlik (Pinder ve Harlos, 2001) dürüstlükten görece uzaklaşmayı da göstermektedir (Gentile, 2010). Yaşam doyumunun temel mekanizmalarından olan bireylerarası iletişim ve sosyal etkileşim süreci (Diener ve Biswas-Diener, 2001; Diener ve Seligman, 2002) ve adalet alg1S1 (Dabbagh, Esfahani, ve Shahin, 2012, Tulubas ve Celep, 2012) zedelenmekte ve örgütsel sessizlik davranışı ortaya çıkmaktadır.

Bireyi erdemli bir yaşam yaşaması, içsel güçlerini kullanabilmesi yaşam doyumu ve mutluluğun en önemli anahtarı olarak görülmektedir (Peterson ve Seligman, 2004). Muhakeme, eleştirel düşünme, dürüstlük, katılımcilık, yaratıcilık, cesaret, adalet, şevk, umut, iyimserlik yaşam doyumunu destekleyen temel içsel güçler ve erdemlerdir (Seligman, 2007, s.156-176). Örgütsel sessizlikte ise birey çeşitli nedenlerle baskılandığından evrensel olarak geçerli bulunan içsel güçlerini, doğrularını, değerlerini yeterinde ortaya koyamamakta, bunları yaşamına geçirememektedir. Örgütsel sessizliğin sözkonusu yaratıcllık, katılımc1lık, adalet dürüstlük gibi içsel güç etmenleriyle olumsuz ilişkisi, yaşam doyumu ile de ilişkisinin olumsuz olabileceğini düşündürmektedir.

\section{Kişilik ve Örgütsel Sessizlik}

Benzer durumlarda bazı bireyler sessiz kalırken, bazı bireyler konuşma davranışını göstermesi ilginçtir. $\mathrm{Bu}$ durum, örgütsel sessizlik davranışında bireysel farklılıkların rolüne vurgu yapmaktadır. Bireyi tanımlayan, diğerlerinden ayırt edebilen görece kalıcı özellikler (Eynseck, 1995) olarak tanımlanan kişilik davranışsal, sosyal, bilişsel, insancıl, psikanalitik ve özellik yaklaşımlarıyla açıklanabilmektedir. Özellik yaklaşımı ölçüm kolaylığı sağlaması, kolay uygulanabilmesi, farklı değişkenlerle kıyaslama yapılabilmesi gibi nedenlerle örgütsel çalışmalarda avantaj sağlamaktadır (Hogan, Hogan ve Robert,1996).

Kişilik özellik yaklaşımında genellikle sıfatlarla belirlenmekte ve faktör analizleriyle sinıflandırılma yapıl- maktadır. Özellik yaklaşımında farklı türde ve boyutta sınıflamalar yapılsa da beş faktör modeli örgütsel çalışmalarda yüksek geçerliği ve güvenirliği nedeniyle en sık tercih edilen yaklaşım olmuştur (Mount veBarrick, 1991). Söz konusu beş faktör dişadönüklük, uyumluluk (geçimlilik), duygusal dengelilik, gelişime (yenilik ve değişime) açıklık ve sorumluluktur.

Dışadönüklük baskın, enerjik, aktif, arkadaş çevresi geniş olma, diğer bireylerle daha çok iletişime geçmeyle ilişkilidir. Duygusal dengelilik, nevrotik olmama, daha sakin, soğukkanl, iyimser olma durumuyla açıklanmaktadır. Gelişime açıklık, yeniliklere, farklılıklara meraklı olma, kolayca benimseme, yaratıcı ve yenilikçi olma ile açıklanmaktadır. Uyumluluk güvenilir, sempatik, bağışlayıcı olma, düşük ben merkeziyetçilik ve işbirlikçilik özellikleriyle özdeşleştirilmektedir. Sorumluluk bireyin hedefleri doğrultusunda gösterdiği gayretlilik, irade, disiplin, planlılık ve mükemmeliyetçilik ile açımlanmaktadır (Çetin ve Varoğlu, 2009, Taymur ve Türkçapar, 2012, )Kişilik özelliklerinin ayrıntılı açıklamalarına bakıldığında bireylerin diğer bireylerle olan sosyal ilişkilerine ve sağlıklı iletişim becerilerine odaklanıldığg görülmektedir.

Premeaux ve Bedeian (2003) sessizliğin bireyin kişilik yapısından kaynaklanan psikolojik etmenlerden kaynaklandığını belirtmektedir. Kendini daha çok izleyen/ dinleyen bireylerin sessiz kalma olasılıkları daha yüksektir. Nikalau, Vakula ve Bountoros (2008) sorumluluk ve duygusal dengelilik özelliklerinin konuşma davranışının en önemli belirleyicileri olduğunu belirlemiştir. Janssen, De Vries ve Cozijnsen (1998) uyumlu/uyum sağlayabilen ve yaratıcı özellikteki bireylerin konuşma davranışlarını karşılaştırmıştır. Yaratıcı bireyler genellikle çözüme ve yaşadıkları doyuma göre konuşma davranışını gerçekleştirmektedir. Var olan duruma uymayı seçen bireyler genellikle olumsuz durumlar hakkında konuşma davranışı göstermektedir.

Bireylerin yaşam doyumlarında da kişilik en önemli belirleyicilerdendir (Hayes ve Joseph, 2003). Özellikle duygusal dengelilik, dışadönüklük ve sorumluluk özelliklerinin yaşam doyumunda önemli miktarda varyans açlklamaktadır (DeNeve ve Cooper, 1998). Kendine güven, genellenmiş öz-yeterlik (generalized selfefficacy), denetim odağı (locus of control) ve duygusal dengesizlik (neurotism) kavramlarıla tanımlanan temel kendini değerlendirme (core self-evaluation) öğelerinin yaşam doyumuyla ilişkisi $(\mathrm{r}=.62, \mathrm{p}<.001)$ olarak belirlenmiştir (Heller, Judge ve Watson, 2002). 
Kişilik araştırmaları kısaca özetlendiğinde özellikle beş faktör modelindeki dişadönüklük, duygusal dengesizlik ve sorumluluk özellikleri, yaşam doyumu ve örgütsel sessizlik farklılıklarını ortaya çıkarmaktadır. Kişilik özellikleri kültürlerarası varyansa sahiptir (Sümer vd. 2000 ). Bu çalışmada kişiliğin ele alınmasının nedeni örgütsel sessizlik yaşam doyumu ilişkisinde kişiliğin rolünü kendi kültürümüzde sorgulamaktır. Böylece, örgütsel sessizliğin kalıtsal yönü de aydınlatılabilecektir. Hangi kişilik özelliklerinin hangi tür örgütsel sessizliği tetiklediği belirlenecek ve örgütsel sessizliğe ilave olarak kişilik özelliklerinin yaşam doyumunda açıkladığı ilave varyans açıklanabilecektir.

\section{Araştırmanın Amacı}

Araştırmanın amacı; örgütsel sessizliğin kişilik özellikleri ve yaşam doyumu ile etkileşiminin ortaya koyulmasıdır. Bu amaç bağlamında ulaşmak için aşağıdaki sorulara yanıt aranmıştır;

1. Bireylerin örgütsel sessizlik tutumları (alt boyutları dâhil) ile kişilik özellikleri ve yaşam doyumu algıları arasındaki ilişki nasıldır?

2. Örgütsel sessizlik tutumları ve kişilik özellikleri yaşam doyumundaki varyansı ne ölçüde açıklamaktadır?

3. Yaşam doyumu algıları ve kişilik örgütsel sessizliğe ilişkin varyansı ne ölçüde açıklamaktadır?

4. Düşük ve yüksek yaşam doyumu sınıflandırmasına göre örgütsel sessizlik ve kişilik puanları farklılaşmakta mıdır?

5. Demografik değişkenler (eğitim durumları, meslek, cinsiyet, statü ve medeni durum) bağlamında bireylerin örgütsel sessizlik tutumları, kişilik özellikleri, yaşam doyumları ve kişilik yapıları ortalamaları farklılaşmakta mıdır?

\section{Araştırma Yöntemi}

$\mathrm{Bu}$ araştırmada kamu çalışanlarının örgütsel sessizlik, kişilik ve yaşam doyumu algıları arasındaki etkileşimi incelemek amaciyla nicel paradigma kapsaminda karma model (betimsel model, ilişkisel model, karşılaştırmalı model) kullanılmıştır. Değişkenler ve alt boyutlarını içeren araştırma modeli Şekil 1.de sunulmuştur.

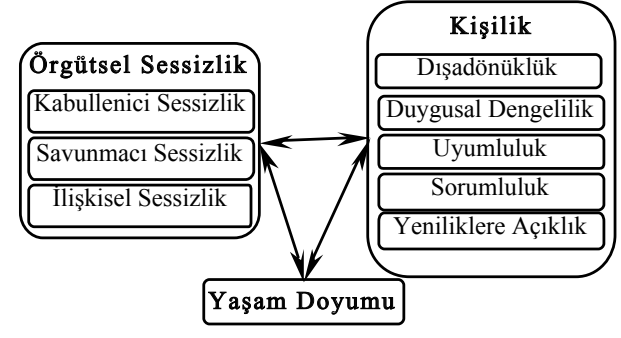

Şekil 1. Araştırma Modeli

Betimsel araştırma modelinde; örnekleme ait betimsel istatistik sonuçları (örneklem sayısı, minimum ve maksimum puanlar, ortalama ve standart sapmalar) rapor edilmiştir. İliş̧kisel model kapsamında; örgütsel sessizlik, kişilik ve yaşam doyumu ölçeklerine ilişkin korelâsyon tabloları incelenmiştir. Karşılaştırmalı model temelinde; örgütsel sessizlik, kişilik ve yaşam doyumu ortalamalarının farklılaşması varyans analizleriyle test edilmiştir. Regresyon analizleriyle örgütsel iletişim ve kişiliğin yaşam doyumundaki varyansın ne kadarını açıladığı araştırılmıştır.

\section{Ana Kütle ve Örneklem}

$\mathrm{Bu}$ araştırmanın ana kütlesini İstanbul'da bir kamu işletmesi çalışanları ile bir kamu üniversitesindeki akademisyen ve idari kadrolardaki çalışanlar oluşturmaktadır. Her iki işletme çalışanlarının tamamı araştırma hakkında bilgilendirilerek araştırmaya davet edilmiş, ancak185 birey araştırmaya katılmıştır. Ölçeklerin uygulanma süreci 2 aylık bir sürede gerçekleştirilmiştir. Ölçekler web üzerinden ve basılı olarak katılımcılara ulaştırılarak gönüllülük esasına göre veriler toplanmıştır.

\section{Veri Toplama Araçları}

Bu araştırmada veri toplama araçları olarak "Demografik Bilgi Formu, Örgütsel Sessizlik, Kişilik, Yaşam Doyumu ve Yaşam Alanlarındaki Doyum Ölçekleri” kullanılmıştır.

Demografik Bilgi Formu: Cinsiyet, yaş, eğitim durumu, meslek, statü, yetiştiği yer, anne ve babanın eğitim durumu, medeni durum, çocuk ve kardeş sayıs1na ilişkin soruları içermektedir.

Örgütsel Sessizlik Ölçeği: Dyne, Soon ve Botero (2003) tarafından geliştirilen ölçek toplam 15 ifadeden oluşmaktadır. Ölçek, ilgisizlik ve boyun eğ- 
meye ilișkin "kabullenici sessizlik" korku ve kendini korumaya ilișkin "savunmacı sessizlik" ve ilișkileri korumaya yönelik "ilişkisel sessizlik boyutlarından oluşmaktadır. Her boyut beș maddeyle ölçülmektedir (Dyne vd., 2003).

Sessizlik ölçeği, Taşkıran (2010) tarafından Türkçeye uyarlanmıştır. Söz konusu çeviri, araştırmacılar tarafından orijinal ölçekle karşılaştırılmış, bazı ifadeler düzenlenmiştir. Yapı geçerliği doğrulayıcı faktör analiziyle test edilmiştir. "İşletme ve iş arkadaşlarım ile olumlu işbirliğimizden dolayı gizli kalması gereken bilgileri kendime saklarım" ifadesi, düşük faktör yükünden dolayı çıkarılmıştır.14 maddelik ölçeğin Cronbach alpha güvenirlik katsayısı .820 olarak hesaplanmıştır.

Yaşam Doyumu Ölçeği (The Satisfaction with Life Scale): Diener, Emmons, Larsen ve Griffin (1985) tarafından geliştirilen ölçek genel yaşam doyumunu ölçmektedir. 1-7 dereceli Likert tipinde, beş maddeden oluşmaktadır. Önceki çevirilerdeki bazı anlam ve çeviri hataları nedeniyle ölçek Şimşek (2011) tarafindan tekrar Türkçeye çevrilmiştir. Cronbach alpha güvenirlik katsayısı .87, Yaşam alanlarındaki doyum ölçeğiyle paralel test geçerliği $\mathrm{r}=.752(\mathrm{p}<.01)$ olarak hesaplanmıştır.Bu çalışmadaki Cronbach alpha güvenirlik katsayıs1 .907'dir.

Yaşam doyumu ölçek maddeleri şunlardır:

(1) Yaşamımdan memnunum.

(2) Yaşamımda sahip olmak istediğim önemli şeyleri elde ettim.

(3) Yaşamım pek çok yönüyle idealimi karşılamaktadir.

(4) Yeniden dünyaya gelseydim yaşamımda hiçbir şeyi değiştirmezdim.

(5) Yaşam koşullarım mükemmeldir.

Beş Faktör Kişilik Ölçeği (Ten Item Personality Inventory-TIPI):Gosling, Rentfrow ve Swann (2003) tarafından geliştirilen kişilik ölçeği 10 maddeden oluşmaktadır. Beş Faktör Envanteri (BigFive Inventory-John ve Srivastava, 1999) ile paralel test geçerliliği $r=.77$ 'dir. 1-7 dereceli Likert tipi bir ölçektir. Alanyazında yaygın olarak uygulanan beş kişilik özelliği olan duygusal dengelilik, dışadönüklük, de- neyime açıklık, uyumluluk ve sorumluluk boyutlarını ikişer madde ile ölçmektedir. Zaman tasarrufu sağlaması nedeniyle, kişiliğin temel ölçüm amacı olmadığı araştırmalarda kısa envanterlerin kullanılması önerilmektedir. Ölçeğin güvenirlik değeri $(\alpha=, 65)$ olarak tespit edilmiştir.

\section{Araştırmanın Kısıtları}

Bireysel ve örgütsel bağlamda olumsuz anlamlar yüklenen ve gizli kalan sessizlik davranışının açıklanması konusunda katılımcıların tereddüt göstermesi söz konusu olabilir. Bu araştırma; İstanbul'daki bir kamu işletmesindeki çalışanlar (mühendisler) ile yine İstanbul'daki bir kamu üniversitesi çalışanları (akademik ve idari personel) üzerinde uygulanmıştır. Sonuçların genellenebilmesi için daha çeşitli ve büyük örneklemde çalışmaların yapılması gereklidir.

\section{Bulgular ve Yorumlar}

Araştırmaya katılan185bireye ait verilerden, eksik veriler ve uç yanıtlayıcıların verileri ayıklanmıştır. 173katılımcının verileri analiz edilmiştir. Öncelikle verilerin doğruluğu kontrol edilmiş, eksik verisi olan 7 katılımcının ve $\mathrm{Z}<-3,29$ ve $Z>3,29$ aralığındaki5 tek değişkenli uç yanıtlayıcının verisi silinmiştir. Temel regresyon ve varyans analizi varsayımları olan normallik ve doğrusallık (test edilmiştir.Varsayımlar karşılanmaktadır.

\section{Demografik Bulgular}

Araştırmaya katılan 173 kişiye ait statü, cinsiyet, yaş, medeni durum, eğitim durumu, meslek, sektör, yetiştiği yer, anne ve baba eğitim durumu, çocuk ve kardeş sayısı bağlamında demografik verilerinin frekans analizi aşağıdaki gibidir.

Statü: Araştırma örneklemi 70yönetici $(\% 44,5)$ ve 103 çalışandan $(\% 59,5)$ oluşmaktadır.

Cinsiyet: Araştırmaya katılanların 114'üerkek $(\% 65,9)$ ve 59’u kadınlardan (\% 34,1) oluşmaktadır.

Yaş: Katılımcıların 43’ü $(\% 24,9)$ 23-30 yaş aralığında, 51'i $(\% 29,5)$ 31-35 yaş aralığında, 44'ü $(\% 25,4) 36-40$ yaş aralığında ve 35 'i $(\% 20,2)$ de 41 yaş ve üzerinde olan bireylerden oluşmaktadır.

Medeni Durum: Katılımciların 121'ievli $(\% 69,9), 48$ 'i $(\% 27,7)$ bekâr ve 4'ü boşanmış (\% $2,3)$ bireylerdir. 
Eğitim Durumu: Lisans düzeyinde 55 (\%31,8) kişi, yüksek lisans düzeyinde 77 (\%44,5) kişi ve 41 (\% 23,7) kişi de doktora düzeyinde eğitimlidirler.

Meslek: Mühendisler 83 (\%48) kişi, akademisyenler 38 kişi (\%22) ve idari kadrolarda görev yapanlar 52 (\%30) kişidir.

Yetiştiği yer: Kasabada yetişenler 14 kişi $(\% 8,1)$ olup katılımciların önemli bölümü 158 kişi $(\% 91,9)$ yaşamlarının büyük çoğunluğunu şehirlerde geçirmişlerdir.

\section{Betimleyici İstatistikler}

Bu bölümde örgütsel sessizlik, kişilik ve yaşam doyumu ölçeklerinin minimum-maksimum puanları, ortalama değerler ve standart sapmalar incelenmiştir.

Örgütsel sessizlik ölçeğine ilişkin betimsel istatistik sonuçları Tablo 1'dedir. Örgütsel sessizlik toplam puan ortalaması $(\mathrm{M}=3.63, \mathrm{SS}=.71)$ olarak belirlen- miştir. Katılımcıların genel olarak sessizlik ortalama puanlarının yüksek olduğu görülmektedir. Sessizlik alt faktörlerine bakıldığında kabullenici sessizlik $(\mathrm{M}=2.63, \mathrm{SS}=1.03)$ ve savunmacı sessizlik $(\mathrm{M}=2.25$, $\mathrm{SS}=1.31$ )değerleri oldukça yakındır. Buna karşılık en yüksek ortalama değerin ilişkisel sessizlik $(M=6.62$, $\mathrm{SS}=.56$ ) boyutunda olması dikkat çekicidir. Bireyler daha çok ilişkilerini korumak için sessiz kalmaktadır.

Yaşam doyumu ölçeğinin betimleyici istatistiği Tablo 2'dedir. Yaşam doyumu toplam puanortalaması 1-7 aralığına göre $(\mathrm{M}=4.54, \mathrm{SS}=1.13)$ olarak belirlenmiştir. Bu değer 100 üzerinden 64,79’a denk gelmektedir. En yüksek madde ortalaması "madde(1)" $(M=5.01, S S=1.17)$, en düşük madde ortalaması "madde(4)"dedir. (M=3.88, SS=1.60). "Madde(4)" aynı zamanda katılımcılar arasında en fazla görüş farklılı̆̆ının olduğu maddedir (SS=1.60). Benzer sonuçlara, aynı ölçeğin kullanıldığı Şimşek'in (2011) çalışmasında da ulaşılmıştır.

Tablo 1. Örgütsel Sessizlik Ölçeğinin Betimleyici İstatistiği

\begin{tabular}{l|ccccc}
\hline \multicolumn{1}{c|}{ Örgütsel Sessizlik } & N & Min. & Maks. & Ort. & Std.Sap. \\
\hline Kabullenici Sessizlik & 173 & 1,00 & 6,00 & 2,63 & 1,03 \\
\hline Savunmacı Sessizlik & 173 & 1,00 & 6,60 & 2,25 & 1,31 \\
\hline Ilişkisel Sessizlik & 173 & 4,25 & 7,00 & 6,62 &, 56 \\
\hline Örgütsel Sessizlik (Toplam Ort.) & 173 & 2,57 & 6,14 & 3,63 &, 71 \\
\hline
\end{tabular}

Tablo 2. Yaşam Doyumu Ölçeğinin Betimleyici Istatistiği

\begin{tabular}{|c|c|c|c|c|c|}
\hline Yaşam Doyumu & $\mathbf{N}$ & Min. & Maks. & Ort. & Std.Sap. \\
\hline Yașamımdan memnunum. & 173 & 1,00 & 7,00 & 5,01 & 1,17 \\
\hline $\begin{array}{l}\text { Yaşamımda sahip olmak istediğim önemli şeyleri elde } \\
\text { ettim. }\end{array}$ & 173 & 1,00 & 7,00 & 4,87 & 1,23 \\
\hline Yaşamım pek çok yönüyle idealimi karşılamaktadır. & 173 & 1,00 & 7,00 & 4,67 & 1,28 \\
\hline $\begin{array}{l}\text { Yeniden dünyaya gelseydim yaşamımda hiçbir şeyi } \\
\text { değiştirmezdim. }\end{array}$ & 173 & 1,00 & 7,00 & 3,88 & 1,60 \\
\hline Yașam koșullarım mükemmeldir. & 173 & 1,00 & 7,00 & 4,24 & 1,31 \\
\hline Toplam Genel Yaşam Doyumu & 173 & 1,00 & 7,00 & 4,54 & 1,13 \\
\hline
\end{tabular}

Kişilik ölçeğinin, 1-5 puan aralığında ölçülen 10 maddenin beş büyük faktör bazında minimum-maksimum puanları, ortalama değerler ve standart sapmalar Tablo 3'de verilmiştir. En yüksek ortalamanın sorumluluk ( $\mathrm{M}=4.27, \mathrm{SS}=.67)$, en düşük ortalamanın duygusal dengelilik $(M=3.19, S S=.97)$ özelliklerinde olduğu belirlenmiştir.

\section{Korelâsyon Analizleri}

Bireylerin örgütsel sessizlik tutumları ile yaşam doyumu algıları ve kişilik yapıları arasındaki ilişkiyi belirlemek üzere;Tablo 4'de araştırma değişkenlerine ait Pearson korelâsyon katsayıları verilmiştir. 
Tablo 3. Örgütsel Sessizlik Ölçeğinin Betimleyici İstatistiği

\begin{tabular}{l|ccccc}
\hline \multicolumn{1}{c|}{ Kişilik } & N & Min. & Maks. & Ort. & Std. Sap. \\
\hline Dışadönüklük & 173 & 1,50 & 5,00 & 3,97 &, 86 \\
\hline Uyumluluk & 173 & 2,00 & 5,00 & 3,81 &, 84 \\
\hline Sorumluluk & 173 & 2,00 & 5,00 & 4,27 &, 67 \\
\hline Duygusal Dengelilik & 173 & 1,00 & 5,00 & 3,19 &, 97 \\
\hline Yeniliklere Açılık & 173 & 2,00 & 5,00 & 4,11 &, 72 \\
\hline
\end{tabular}

\section{Tablo 4. Yaşam Doyumu ile Örgütsel Sessizlik ve Kişilik ilişkisi}

\begin{tabular}{|c|c|c|c|c|c|c|c|c|}
\hline & 2 & 3 & 4 & 5 & 6 & 7 & 8 & 9 \\
\hline III. Kabullenici Sessizlik & $1,476^{* *}$ &,$- 187^{*}$ &,$- 422^{* *}$ &,- 130 &,- 118 &,- 114 &,$- 284^{* *}$ &,$- 174^{\prime \prime}$ \\
\hline IV. Savunmacı Sessizlik & 1 &,$- 158^{*}$ &,$- 193^{*}$ &,- 094 &,- 119 &, 051 &,- 081 &,$- 185^{*}$ \\
\hline V. Ilişkisel Sessizlik & & 1 &, $208^{* *}$ &, 142 &, $220^{* *}$ & ,038 &, $215^{* *}$ &, 054 \\
\hline VI. Dışadönüklük & & & 1 &, 139 &, $253^{* *}$ & ,033 &, $310^{* *}$ &, $155^{*}$ \\
\hline VII. Uyumluluk & & & & 1 &, $159^{*}$ &, $168^{*}$ &, $151^{*}$ &, 090 \\
\hline VIII. Sorumluluk & & & & & 1 &, $167^{*}$ &, $282^{* *}$ &, $159^{*}$ \\
\hline IX. Duygusal Dengelilik & & & & & & 1 &, $300^{* *}$ &, 014 \\
\hline X. Yeniliklere Açıklık & & & & & & & 1 &,- 018 \\
\hline XI. Yaşam Doyumu & & & & & & & & 1 \\
\hline
\end{tabular}

Tablo 4.de görüldüğü gibi yaşam doyumu algısı, örgütsel sessizlik tutumları ve kişilik ölçeklerinin toplam puanları arasında istatistiksel olarak anlamlı ve güçlü bir ilişki vardır.

Ölçeklerin alt boyutları temelinde en güçlü ve ters yönlü ilişki; kabullenici sessizlik ile "dışadönüklük" kişilik alt boyutu puanı $(\mathrm{r}=-.422, \mathrm{p}<.01)$ arasındadır. Kabullenici sessizlik ile "yeniliklere açıklık" kişilik alt boyutu arasında $(\mathrm{r}=-.284, \mathrm{p}<.01)$ ve "yaşam doyumu algısı" arasında $(\mathrm{r}=-.174, \mathrm{p}<.05)$ anlamlı ve ters yönlü ilişkiler mevcuttur.Kabullenici sessizlik gösterme eğiliminde olanlar içedönük ve yeniliklere daha az açık olanlarıdır. Ayrıca kabullenici sessizlik davranışı gösterenler aynı zamanda yaşam doyumu düşük olma eğiliminde olanlardır.

Savunmacı sessizlik ile "dışadönüklük" kişilik alt boyutu arasında $(\mathrm{r}=-.193, \mathrm{p}<.05)$ ve "yaşam doyumu algısı" arasında $(\mathrm{r}=-.185, \mathrm{p}<.05)$ anlamlı ilişki vardır. Savunmacı sessiz olanlar daha az dışadönük olup daha düşük yaşam doyumuna sahip olma eğilimindedir.

İlişkisel sessizliğin, "dışadönüklük" ( $\mathrm{r}=.208, \mathrm{p}<.01)$, "sorumluluk" ( $\mathrm{r}=.220, \mathrm{p}<.05)$ ve "yeniliklere açıklı" $(\mathrm{r}=.215, \mathrm{p}<.01)$ ile anlamlı düzeyde ilişkisi vardır. İlişkisel sessizlik ile "yaşam doyumu algısı" arasında anlamlı ilişki yoktur.
Ortak noktaları ve farklılıkları ifade etmek gerekirse, hem kabullenici hem savunmacı sessizlik dışadönüklük kişilik özelliği ve yaşam doyumu algısı ile ters yönlü ilişki içerisindedir. Öte yandan yeniliklere açık olma kişilik özelliği ile kabullenici sessizliğin ters ilişki içerisinde olması da bu tür sessizliğin bir iletişim sorunu olarak görülmesinin bir işaretidir.

İlişkisel sessizliğin ise dışadönüklük, sorumluluk ve yeniliklere açılık kişilik özellikleriyle pozitif ilişkisinin olması dikkat çekicidir. İlişkisel sessizlik, kabullenici ve savunmacı sessizliğe göre daha olumlu kişilik özellikleriyle etkileşmektedir. Ancak ilişkisel sessizlik yaşam doyumu ile anlamlı ölçüde etkileşmemektedir.

\section{Regresyon Analizleri}

Regresyon analizlerinde, ortalama alma metoduyla hesaplanan faktör değerleri ile aşamalı regresyon metodu uygulanmıştır (Sevimli ve İşcan, 2005). Regresyon analizlerinde analizlerin geçerliliği için doğrusallık varsayımı incelenmiş; çoklu doğrusal bağıntı problemi için VIF değerleri incelenerek en yüksek değerin 10’dan küçük olduğu ve çoklu bağıntı olmadığı tespit edilmiştir. Otokorelâsyon durumu test edilmiştir. Tüm regresyon analizleri için DurbinWatson katsayılarının 1,5 ile 2,5 arasında dağıldığıve 
otokorelâsyonolmadığı görülmüştür. Regresyon hata terimlerinin varyanslarının sabit olduğu, normal P-P Plot diyagonalinde yer alan doğru üzerinde olduğu, eşdeyişle normale yakın dağıldığı görülmüştür (Orhunbilge, 2002; Sevimli ve İşcan, 2005; Şeref, 2006).

Örgütsel sessizlik alt faktörleri; kabullenici sessizlik (KS), savunmacı sessizlik (SS), ilişkisel sessizlik (İS) ve dışadönüklük (D), uyumluluk (U), sorumluluk (S), duygusal dengelilik (DD), yeniliklere açıklık (YA) kişilik alt faktörlerinin yaşam doyumu üzerindeki etkilerini belirlemeye yönelik yapılan regresyon analizi Tablo 5.de sunulmuştur.
Modele göre, bağımlı değişken yaşam doyumundaki varyansın \% 3,4'ü bağımsız değişken savunmacı sessizlik tarafından açıklanmaktadır. Modeldeki diğer değişkenler; kişiliğin tüm alt boyutları ve örgütsel sessizliğin kabullenici ve ilişkisel sessizlik alt boyutları yaşam doyumundaki varyansı açıklamada istatistikî olarak anlamlı bir sonuç vermemiştir. Savunmacı sessizlik davranışı arttıkça, yaşam doyumunun azaldığ 1 görülmektedir.

Bireylerin genel yaşam doyumlarının sessizlik davranışı üzerindeki etkilerini de belirleyebilmek amacıyla yaşam doyumu ile kişilik alt boyutları da bağımsız

Tablo 5. Örgütsel Sessizlik ve Kişilik Alt Faktörlerinin Yaşam Doyumu üzerindeki Etkilerinin Regresyon Analizi Sonuçları

\begin{tabular}{|c|c|c|c|c|c|c|}
\hline & $\mathrm{R}$ & $\mathrm{R}^{2}$ & $\begin{array}{c}\text { Düzeltilmiş } \\
\mathrm{R}^{2}\end{array}$ & $\beta$ & $t$ & $p$ \\
\hline 1 &, $185^{a}$ & ,034 & ,028 & -185 & $\begin{array}{r}29,028 \\
-2,459\end{array}$ & $\begin{array}{l}000 \\
, 015\end{array}$ \\
\hline
\end{tabular}

değişkenler, örgütsel sessizlik alt boyutları bağımlı değişken olarak bir seri regresyon analizi yapılmıştır. İlk olarak bireylerin kabullenici sessizlik davranışlarında kişilik ve yaşam doyumunun rolü sorgulanmıştır. Sonuçlar Tablo 6.da sunulmuştur.
Modele göre kabullenici sessizlik tutumlarındaki varyansın \% 20,4'ü dışadönüklük ve yeniliklere açıklık bağımsız değişkenlerince açılanmaktadır. Regresyon modeli ve değişkenlerin modelin açıklayıcı gücüne olan katkıları Tablo 6.da görülmektedir.

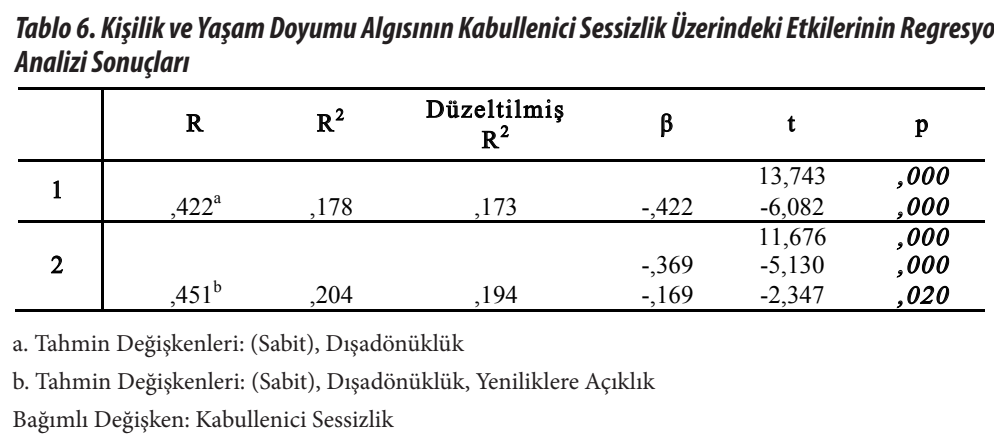

Kişilik özellikleri kabullenici sessizlikteki varyansın \% 17,8'inidışadönüklük açıklamaktadır. Yeniliklere açık olma kişilik özelliği ise ilave olarak kabullenici sessizlikteki varyansın\% 2,6'sınıaçıklamaktadır. Eşdeyişle, dişadönük ve yeniliklere açık olanlar, daha az kabullenici sessizlik göstermektedir. Yaşam doyumu- nun yüksek ya da düşük olması kabullenici sessizliği belirlememektedir.

İkinci olarak savunmacı sessizlik tutumları üzerinde kişilik ve yaşam doyumunun etkileri sorgulanmış, regresyon analizi sonuçları Tablo 7.de sunulmuştur. 
Tablo 7. Kişilik ve Yaşam Doyumu Algııının Savunmacı Sessizlik Üzerindeki Etkilerinin Regresyon Analizi Sonuçları

\begin{tabular}{c|cccccc}
\hline & $\mathrm{R}$ & $\mathrm{R}^{2}$ & $\begin{array}{c}\text { Düzeltilmiş } \\
\mathrm{R}^{2}\end{array}$ & $\beta$ & $\mathrm{t}$ & $\mathrm{p}$ \\
\hline 1 &, $193^{\mathrm{a}}$ &, 037 &, 032 &,- 193 & 7,342 &, 000 \\
\hline \multirow{2}{*}{2} & & & & & $-2,573$ &, 011 \\
\hline & \multirow{2}{*}{, $249^{\mathrm{b}}$} & \multirow{2}{*}{, 062} & \multirow{2}{*}{051} &,- 169 & 7,279 &, 000 \\
& & &,- 159 & $-2,242$ &, 026 \\
\hline
\end{tabular}

a. Tahmin Değişsenleri: (Sabit), Dışadönüklük

b. Tahmin Değişkenleri: (Sabit), Dışadönüklük, Yaşam Doyumu

Bağıılı Değişken: Savunmacı Sessizlik

Savunmacı sessizlik tutumlarındaki varyansın \% 6,2'si bağımsız değişkenler dışadönüklük (\%3.7), yaşam doyumu algısı (\%2.5)tarafından açılanmaktadır. Yaşam doyumu ve dışadönüklük azaldıkça savunmacı sessizlik davranışı artmaktadır. Eşdeyişle daha mutsuz ve daha içedönük olanlar daha çok savunmac1 sessizlik gösterme eğilimindedir.

Üçüncü olarak ilişkisel sessizlik tutumları üzerinde kişilik alt boyutları ve yaşam doyumunun etkilerine ilişkin regresyon analizi yapılmıştır. Sonuçlar Tablo 8.de özetlenmiştir.
İlişkisel sessizlikteki varyansın \%7.4’ü kişilik özellikleriyle açılanmaktadır. Sorumluluk (\%4.8) ve yeniliklere açıklık (\%2.6)ilişkisel sessizliği yordamaktadır. Sorumluluk ve yeniliklere açılklı kişilik özelliklerine sahip olanlar daha çok ilişkisel sessizlik gösterme eğilimindedir.

Regresyon analizleri bir bütün olarak değerlendirildiğinde;yaşam doyumunu yordamada ilişkisel ve savunmacı sessizlik anlamlı değildir. Ancak yaşam doyumu ve savunmacı sessizlik arasındaki negatif ilişkinin regresyon analizlerinde de ortaya

Tablo 8. Kişilik ve Yaşam Doyumu Algısının İlişkisel Sessizlik Üzerindeki Etkilerinin Regresyon Analizi Sonuçları

\begin{tabular}{|c|c|c|c|c|c|c|}
\hline & $\mathbf{R}$ & $\mathbf{R}^{2}$ & $\begin{array}{c}\text { Düzeltilmiş } \\
\mathrm{R}^{2}\end{array}$ & $\beta$ & $\mathrm{t}$ & p \\
\hline 1 &, $220^{\mathrm{a}}$ & ,048 & ,043 & ,220 & $\begin{array}{r}21,847 \\
2,943 \\
\end{array}$ & $\begin{array}{l}, 000 \\
, 004 \\
\end{array}$ \\
\hline 2 &, $271^{\mathrm{b}}$ & ,074 & ,063, & $\begin{array}{l}, 173 \\
, 166\end{array}$ & $\begin{array}{r}17,417 \\
2,245 \\
2,160\end{array}$ & $\begin{array}{l}, 000 \\
, 026 \\
, 032\end{array}$ \\
\hline
\end{tabular}

a. Tahmin Değișkenleri: (Sabit), Sorumluluk

b. Tahmin Değişkenleri: (Sabit), Sorumluluk, Yeniliklere Açılılık

Bağımlı Değişken: İlişkisel Sessizlik

çıkması dikkat çekicidir. Bireysel korkuya dayalı sessizlik davranışının yaşam doyumunu olumsuz yönde etkilediği görülmektedir. Bireyin kendini savunma durumunda olması ve bu nedenle sessiz kalması örgütteki önemli sorunlara işaret etmektedir. Bu sorunlar yalnızca iş yaşamını etkilememekte, bireyi genel olarak mutsuz etmektedir. Aktaş ve Şimşek (2013) tarafından sessizlik ve iş doyumu arasındaki negatif ilişki, bu araştırmada da savunmacı sessizliğin yaşam doyumundaki belirleyici rolüyle pekiştirilmiştir.
Öte yandan sessizlik davranışında kişiliğin önemli rolü olduğu belirlenmiştir. Dişadönüklük ve yeniliklere açıklık kişilik özelliklerini yüksek değerleyen bireylerin kabullenici sessizlik içinde bulunmayacakları öngörülmektedir. Savunmacı sessizlik davranışı için de durum benzer olup yine dışadönüklük arttıkça savunmacı sessizliğin azalacağı belirlenmiştir. Yaşam doyumu arttıkça savunmacı sessizliğin azalması da dikkat çekicidir. İlişkisel sessizlik boyutunda ise 
sorumluluk ve yeniliklere açıklık kişilik özelliklerine sahip bireylerin daha çok ilişkisel sessizlik davranışı sergileyebileceği görülmektedir.

\section{Varyans Analizleri}

Bireylerin Yaşam Doyumu Düzeyleri Bağlamında Örgütsel Sessizlik ve Kişilik

$\mathrm{Bu}$ çalışmadaki genel yaşam doyumu ortalama ve standart sapma değeri $(\mathrm{M}=4.54, \mathrm{SS}=1.13)$ 'dir. Yaşam doyumu ortalamasının üstünde ve altında olanlar iki grup olarak sınıflandırılmıştır. Yüksek yaşam doyumu grubunda 86 ve düşük yaşam doyumu grubunda 87 katılımcı bulunmaktadır. Genel yaşam doyumu ortalamalarının çeşitli demografik değişkenlere göre ne ölçüde farklılaştığ $\mathrm{t}$ testleri ve tek yönlü varyans analizleriyle test edilmiştir. Yalnızca istatistiksel açıdan anlamlı sonuçlar rapor edilmiştir. Söz konusu farklılıkların değişkenler arasındaki nedensel ilişkiyi açıklamadığı unutulmamalıdır.

Katılımcıların yaşam doyumu sinıflandırmalarına göre (yüksek-düşük) yapılan t-testi analizi sonuçlarına göre kabullenici $[t(171)=2.739, p=.007]$ ve savunmaci sessizlik $[t(171)=2.422, p=.016]$ boyutları ile dişadönüklük kişilik özelliği [ $t(171)=-2.185, p=.030]$ boyutlarında yüksek ve düşük yaşam doyumu gruplarının istatistikî olarak anlamlı farklılık gösterdiği tespit edilmiştir.

Yaşam doyumu düşük olan işgörenlerin kabullenici $(\mathrm{M}=2.84, \mathrm{SS}=1.11)$ ve savunmac1 sessizlik $(\mathrm{M}=2.48$, $\mathrm{SS}=1.35$ ) tutum ortalamaları; yaşam doyumu yüksek olan işgörenlerin kabullenici $(\mathrm{M}=2.42, \mathrm{SS}=.89)$ ve savunmacı sessizlik $(\mathrm{M}=2.01, \mathrm{SS}=1.2)$ tutum ortalamalarından daha yüksektir. Mutsuzların daha büyük olasılıkla kabullenici ve savunmacı sessizlik davranışı gösterme eğiliminde olduğu görülmektedir.

Dışadönüklük kişilik özelliği boyutunda ise yaşam doyumu yüksek olan işgörenlerin dışadönüklük ortalamalarının $(\mathrm{M}=4.11, \mathrm{SS}=.80)$, yaşam doyumu düşük olan işgörenlerden $(\mathrm{M}=3.83, \mathrm{SS}=.90)$ daha yüksek olduğu görülmüştür. Bu sonuca göre dişadönüklük kişilik özelliğine sahip bireylerin yüksek olasılıkla daha mutlu olabileceği değerlendirilebilir.

Elde edilen sonuçlara göre; düşük yaşam doyumu algisına sahip olan bireylerin kabullenici ve savunmacı sessizlik tutumları ortalamaları daha yüksektir.

\section{Sonuç ve Tartışma}

Bu çalışmada, örgütsel sessizliğin, kişilik ve yaşam doyumuyla etkileşimi araştırılmıştır. Korelâsyon analizlerine göre; kabullenici sessizlik ve savunmacı sessizlik ile yaşam doyumu arasında ters yönlü ve anlamlı ilişki vardır. Kabullenme, TDK sözlügünde “istemeyerek kabul etme" olarak, savunma ise "saldırıya karşı koyma” olarak açıklanmaktadır. Kabullenme, çözümlenemeyen olumsuz bir duruma ilişkin bireyin içselleştirme tepkisi olup pasif niteliktedir. Savunma ise kabullenmeye göre daha aktif bir tepkidir. Hem kabullenici sessizlik, hem de savunmaci sessizlik, genellikle örgüt yaşamındaki olumsuzluklardan kaynaklanmaktadır.

Kabullenici ve savunmacı sessizlik artarken yaşam doyumunun azalması,söz konusu olumsuzlukların bireyi mutsuz edebileceğine işaret etmektedir. Regresyon analizlerine göre yaşam doyumunda etkili tek değişken savunmacı sessizliktir. Bireyin savunmac1 sessizlik durumunda kalması, mutsuzluğuna yol açmaktadır.Savunmacı sessizlik niçin kabullenici sessizliğe göre daha çok bireyi mutsuz etmektedir sorusunun yanıtı içsel mekanizmalarla açıklanabilir. Savunma durumu kabullenme durumuna göre daha çok uyarılmış olmayı, soruna odaklanmayı gerektirmektedir. Kabullenmede ise olumsuz durumdan dikkat dağılmış, birey çevresiyle görece daha barışık hale gelmiştir. Başka bir deyişle bireylerin değerlerine tezat olan duruma ilişkin bilişsel uyumsuzluğun kabullenme ile azaltıldığı, savunma ile baskın hale getirildiği düşünülmektedir.

Betimsel istatistik sonuçlarına göre, ilişkisel sessizlik ortalamasinin $(\mathrm{M}=.6 .62, \mathrm{SS}=.56)$, kabullenici $(\mathrm{M}=$ $2.63, \mathrm{SS}=1.03)$ ve savunmacl $(\mathrm{M}=2.25, \mathrm{SS}=1.31)$ sessizlik türlerine göre oldukça yüksek olması, ilişkisel sessizliğin bireyler tarafından daha çok benimsendiğini göstermektedir. İlişkisel sessizlik başkalarına yardım etme, koruma, aşkınlık gibi olumlu etmenlerle örtüşmektedir. Kabullenici sessizlik, dışadönüklük ve yeniliklere açıklık ile savunmacı sessizlik ise dışadönüklük ile ters yönde ilişkilidir. İlişkisel sessizlik dışadönüklük, sorumluluk ve yeniliklere açılılı ile olumlu yönde ilişkili olup yaşam doyumuyla ilişkisi anlamlı değildir.

Kabullenici ve savunmacı sessizlik ile ilişkisel sessizliğin hem kişilik özellikleri hem de yaşam doyumu bağlamında ayrıştığı değerlendirilmektedir. Kabulle- 
nici sessizlik ile savunmacı sessizlik arasındaki yüksek korelâsyon $(\mathrm{r}=.476, \mathrm{p} \leq .01)$ bu görüşü desteklemektedir. İlişkisel sessizlik daha çok olumlu kişilik özellikleriyle özdeşleşmektedir.

Bireylerin örgütsel sessizlik davranışları ve sessizliğe yönelik nedenleri ve stratejileri kişilikleriyle güçlü bir biçimde etkileşmektedir. Kabullenici sessizlik tutumlarına ilişkin varyansın \% 20,4'ünün dışadönüklük ve yeniliklere açıklık bağımsız değişkenlerince açıklanması oldukça dikkat çekicidir. Dışadönük ve yeniliklere açık olanlar, daha az kabullenici sessizlik davranışını göstermektedirler. Dışadönüklük savunmacı sessizlik üzerindeki varyansın \%6.2'sini açıklamaktadır. Dışadönükler daha az savunmacı sessizlik davranışı göstermektedir. Sorumluluk ve yeniliklere açıklık ise ilişkisel sessizlikteki varyansın \%7.4'ünü açıklamaktadır. Sorumlu ve yeniliklere açık olanlar, daha çok ilişkisel sessizlik göstermektedir.

Düşük yaşam doyumu olan bireylerin, yüksek olanlara göre kabullenici ve savunmacı sessizlik ortalamaları daha yüksektir. Eşdeyişle mutsuz olanların sessiz olma olasılıkları daha yüksektir. Bu durum yaşam doyumunun örgütsel yaşamdaki pratikleri kapsayan bir değişken olabileceğini göstermektedir.Sonuç olarak örgütsel sessizlik kişilikle güçlü bir şekilde ilişkilidir. Kişilik yapısı hangi tür örgütsel sessizliğin gösterileceği konusunda belirleyicidir. Özellikle savunmacı sessizliğin bireyi mutsuz ettiği ve yaşam doyumunu azalttığı belirlenmiştir. Birey örgütsel yaşamda söyledikleri kadar söylemedikleriyle de bir iletişim davranışı oluşturmaktadır.

Bu çalışmada örgütsel sessizliğin kuramsal yapısının yeni bulgularla pekiştirilmesi hedeflenmiştir. Örgütsel sessizliğin yaşam doyumuyla olumsuz ilişkisi alanyazında ilk kez dolaysız olarak belirlenmiştir. Örgütsel sessizlik çoğunlukla güvenin, açık iletişimin olmadığı durumlarda ortaya çıkmakta ve yaşam doyumunun azalmasına neden olmaktadır. Bir iletişim sorunu olan örgütsel sessizliğin yalnızca örgütle s1nırlı bir sorun olmadığını ve bireyin mutluluğu gibi daha geniş ve farklı bir perspektiften bakılması gerektiğini ortaya çıkmıştır.

Örgütsel sessizlik sorununa ilişkin kişilik ve yaşam doyumunu temel alan yeni yaklaşımların soruna ilişkin çözüm yollarını zenginleştirme potansiyeli bulunmaktadır. Şimşek (2011) tarafından önerilen olumlu örgütsel iletişim yaklaşımının önemi, örgüt- sel sessizlik kavramıyla bir kez daha anlaşılmıştır. Olumlu örgütsel iletişim, bireylere yönelik doğru, dürüst, açık, güvenilir örgütsel iletişim uygulamalarıyla yaşam doyumlarının yükseltilmesi anlayışına dayanmaktadır. Bireye sağlanan güven ortamı, sağlıklı iletişim pratikleri, örgüt kültürü ve iklimi örgütsel sessizliği azaltarak bireyin mutluluğunu artırmasına olanak sağlayacaktır.

\section{Kaynakça}

ACCI, BCA. (2002). Employability skills for the future. Australian Chamber of Commerce and Industry ve Business Council of Australia. Canberra. Retrieved at 15 March 2010 from: http://www.dest.gov.au/ sectors/training_skills/ publications_ resources/ other_publications/.

Aktaş, H., Şimşek, E. (2013, Mayıs). Örgütsel sessizlik ve bireysel performans ilişkisinde örgüt kültürünün rolü: Sussan olmuyor, susmasan olmaz. 21. Ulusal Yönetim ve Organizasyon Kongresinde sunulan bildiri. Mayıs 2013. Kütahya: Dumlupınar Üniversitesi

Aktaş, H., Şimşek, E. (2012). Sükût ikrardan gelir mi? İşgörenlerin örgütsel sessizlik davranışlarına ilişkin tutumları ile iş tatmin düzeyleri ve duygusal tükenmişlik düzeyleri arasındaki etkileşim. 20. Ulusal Yönetim ve Organizasyon Kongresi Bildiri Kitabı. 24-26 Mayıs 2012. İzmir: Dokuz Eylül Üniversitesi İşletme Fakültesi, 330-335.

Alparslan, A. M., Kayalar, M. (2012). Örgütsel sessizlik: Sessizlik davranışları ve örgütsel ve bireysel etkileri. Mehmet Akif Ersoy Üniversitesi Sosyal Bilimler Enstitüsü Dergisi, 4(6), 136-147.

Barçın, N. (2012). İşletmelerde örgütsel sessizliğin örgütsel bağlılık ve iş tatminine etkisi üzerine bir araştırma. Yayımlanmamış Yüksek Lisans Tezi. Adana: Çukurova Üniversitesi.

Barrick, M.R., Mount, M.K. (1991). The big five personality dimensions and job performance: A metaanalysis. Personnel Psychology, 41(1), 1-26.

Beycioğlu, K. (2007). Z kuramı ve okul yönetimine uygulanabilirliği açısından değerlendirilmesi. Kastamonu Eğitim Dergisi, 15(1), 63-72. 
Bienefeld, N., Grote, G. (2012). Silence that may kill: When air crew members don't speak up and why. Aviation Psychology and Applied Human Factors, 2, (1), 1-10. DOI: 10.1027/2192-0923/a000021.

Biswas-Diener, R., Diener, E., Tamir, M. (2004). The psychology of subjective well-being. Daedalus, 133, 18-25.

Carrière, J., Bourque, O.C., Bonaccio, S. (2007). The role of communication satisfaction as a mediator between an organization's internal communication systems and two job outcomes: Job satisfaction and organizational commitment. ASAC, 60-75. http:// libra.acadiau.ca/library/ASAC/v28/05/05_60.pdf.

Cattell, R.B., Eber, H.W., Tatsuoka, M.M. (1970). Handbook of the 16 PF. Illinois: IPAT Inc.

Cortina, L.M., Magley, V.J. (2003). Raising voice, risking retaliation: Events following mistreatment in the work place. Journal of Occupational Health Psychology, 8, 247-265.

Çakıcı, A. (2007). Örgütlerde sessizlik: Sessizliğin teorik temelleri ve dinamikleri. Ç.Ü. Sosyal Bilimler Enstitüsü Dergisi, Sayı 16(1), 145-162.

Çakıcı, A. (2010). Örgütlerde işgören sessizliği: Neden sessiz kalmayı tercih ediyoruz? Ankara: Detay.

Çetin, F., Varoğlu, A.K. (2009). Özellikler bağlamında girişimcinin beş faktör kişilik örüntüsü. Savunma Bilimleri Dergisi, 8(2), 51-66.

Dabbagh, P., Esfahani, A.N., Shahin, A. (2012). Studying relationship between perceived organizational justice and organizational salience. Interdisciplinary Journal of Contemporary Research Business, 3(10), 468-478.

DeNeve, K., Cooper, H. (1998). The happy personality: A meta analysis of 137 personality traits and subjective well being. Psychological Bulletin, 124(2), 197-229.

Detert, J.R., Burris, E.R. (2007). Leadership behavior and employee voice: Is the door really open? Academy of Management Journal, 50, 869-884.

Diener, E.,Biswas-Diener, R. (2001). Making the best of a bad situation: Satisfaction in the slums of Calcutta. Social Indicators Research, 55, 329-352.
Diener, E.,Seligman, M.E.P. (2002). Very happy people. Psychological Science, 13(1), 81-84.

Diener, E., Emmons R.A., Larsen, R.J., Griffin, S. (1985). The satisfaction with life scale. Journal of Personality Assessment, 49(1),71-75.

Dixon, M.A., Sagas, M. (2007). The relationship between organizational support, work-family conflict, and the job-life satisfaction of university coaches. Research Quarterly for Exercise and Sport, 78(3), 236-247.

Downs, C.W., Hazen, M.D. (1977). A factor analytic study of communication satisfaction. Journal of Business Communication, 14(3), 63-73.

Dyne, L.V., Ang, S., Botero, I.C. (2003). Conceptualizing employee silence and employee voice as multidimensional constructs. Journal of Management Studies, 1359-1392.

Ehtiyar, R., Yanardağ, M. (2008). Organizational silence: A survey on employees working in a chain hotel. Tourism and Hospitality Management, 14(1), 51-68.

Eynseck, H.J. (1995). Trait theories of personality. In S.E. Hampson ve M.A. Colman (Eds.). Individual differences and personality. Newyork: Longman, 40-50.

Gentile, M. C. (2010). Managing yourself: Keeping your colleagues honest.Harward Business Review. http://hbr.org/2010/03/managing-yourself-keeping-your-colleagues-honest/ar/1

Gosling, S.D. Rentfrow, P.J., Swann Jr., W.B. (2003). A very brief measure of the Big-Five personality domains. Journal of Research in Personality, 37, 504528.

Gürüz, D., Eğinli, A.T. (2008). İletişim becerileri, anlamak, anlatmak, anlaşmak. Ankara: Nobel.

Hayes, N., Joseph, S. (2003). Big 5 correlates of three measures of subjective well-being. Personality and Individual Differences, 34(4), 723-727.

Henriksen, K., Dayton, E. (2006), Organizational silence and hidden threats to patient safety. Health Services Research, 41, 1539-1554. doi: 10.1111/j.14756773.2006.00564.x 
Huang, X., Van de Vliert E., Van der Vegt, G. (2005). Breaking the silence culture: Stimulation of participation and employee opinion withholding crossnationally. Management and Organization Review, 1(3), 459-482.

Janssen, O., De Vries T., Cozijnsen, A.J. (1998). Voicing by adapting and innovating employees: An empirical study on how personality and environment interact to affect voice Behavior. Human Relations, 51, 945-967.

John, O.P. , Srivastava, S. (1999). The big-five trait taxonomy: History, measurement, and theoretical perspectives. http://citeseerx.ist.psu.edu/viewdoc/dow nload? $\mathrm{doi}=10.1 \cdot 1.133 .2251$ verep $=$ rel vetype $=$ pdf.

Kalaycı, Ş. (2006). SPSS Uygulamalı Çok Değişkenli İstatistik Teknikleri.2'nci Baskı, Ankara: Asil.

Keser, A. (2005). Çalışma yaşamı ile yaşam doyumu ilişkisine teorik bakış. İktisat Fakültesi Mecmuası, (Prof. Dr. Toker Dereliye Armağan Özel Sayıs1), İstanbul, İ.Ü. İktisat Fakültesi Yayını, 55, (1), 898913.

Knoll, M., Van Dick, R. (2013). Authenticity, employee silence, prohibitive voice, and the moderating effect of organisational identification. The Journal of Positive Psychology, 8(4), 346-360.

Milliken, F.J.,Morrison, E.W. (2003).Shades of silence: Emerging themes and future directions for research on silence in organizations. Journal of Management Studies, 40(6), 1564-1568.

Milliken, F.J., Morrison, E.W. ve, Hewlin P.F. (2003). An exploratory study of employee silence: Issues that employees don't communicate upward and why. Journal of Management Studies, 40, 14531476. DOI: 10.1111/1467-6486.00387.

Morrison E.W. ve, Milliken F.J. (2000). Organizational silence: A barrier to change and development in a pluralistic world. The Academy of Management Review, 25(4), 706-725.

Morrison, W.,Milliken, F.J. (2009). Sounds of silence. www.business.unr.edu/faculty/simmonsb/ badm720/orgsilence.pdf.

Mount, M.K., Barrick, M.R. (1991). The big five personality dimensions and jobperformance: A metaanalysis. Personnel Psychology, 44(1), 1-26.
Nikolaou, I., Vakola, M., Bourantas, D., (2008).Who speaks up at work? Dispositional influences on employees voice behaviour. Personnel Review, 37(6), 666-679.

Nikolaou, I., Vakola, M., Bourantas, D. (2010). The role of silence on employes' attitutes "the day after" a merger. Personnel Review, 40(6), 723-741.

Orhunbilge, N. (2002). Uygulamalı Regresyon ve Korelâsyon Analizi.İkinci Baskı.İstanbul: İstanbul Üniversitesi.

Pearce, C.G., Segal, G.J. (1998). Effects of organizational communication satisfaction on job performance and firm growth in small businesses. http://www.sbaer. uca.edu/ research/1998/ SDIDA/ 98 sbi 178.txt.

Pentilla, C. (2003). Get talking. Enterpreneur, 31(11), 25.

Perlow, L., Williams, S. (2003). Is silence killing your company? Harvard Business Review, 81(5), 52-58.

Peterson, C., Seligman, M.E.P. (2004). Charachter strenghts and virtues: $A$ handbook and classification. Oxford: American Psychological Association.

Pinder, C.C., Harlos, H.P. (2001). Employee silence: quiescense and acquiescence as responses to perceived injustice.Research in Personnel and Human Resource Management, 20, 331-69.

Premeaux, S.F., Bedeian, A.G. (2003). Breaking the silence: The moderating effects of self-monitoring in predicting speaking up in the workplace. Journal of Management Studies, 40(6), 1537-1562.

Rice, R.W. Frone, M.R.,McFarlin, D.B. (1992). Worknonwork conflict and the perceived quality of life. Journal of Organizational Behavior, 13, 155-168, DOI: 10.1002/job.4030130205.

Roberts, K.H., O’Reilly, C.A. (1974). Measuring organizational communication. Journal of Applied Psychology, 59,321-326.

Schimmack, U., Oishi, S., Furr, R.M., Funder, D.C. (2004). Personality and life satisfaction: A facet-level analysis. Personality and Social Psychology Bulletin, 30(8), 1062-1075.

Seligman, M.E.P., Steen, T.A., Park, N., (2005). Positive psychology progress: Emprical validation of interventions. American Psychologist, 60(5), 410-421. 
Seligman, M.E.P. (2007). Gerçek mutluluk. Kalıcı doyum potansiyelinizi geliştirmek için yeni olumlu psikolojinin kullanılması. Ankara: HYB.

Sevimli, F., İşcan, Ö. (2005). Bireysel ve iş ortamına ait etkenler açısından iş doyumu. Ege Akademik Bakış Dergisi, 5 (2), 55-64.

Sharma, E. (2013). Theory Z of motivation-Job satisfaction. <http://www.citehr.com/1898-theory-Zmotivation-job-satisfaction.html\#ixzz2p2jLLaab>.

Sümer, H.C., Sümer, N., Çifci, O.S., Demirutku, K. (2000). Measurement of officer personality attributes: A construct validity study. Turkish Psychological Journal, 15(45), 15-39.

Şimşek, E. (2011). Örgütsel iletiş̧im ve kişilik özelliklerinin yaşam doyumuna etkileri. Basılmamış Doktora Tezi. Eskişehir: Anadolu Üniversitesi.

Tahmasebi, F., Sobhanipour, S.M., Aghaziarati, M. (2013). Burnout: explaining the role of organizational silence on its influence (Case study: Selected executive organizations of qom province). Journal of Basic and Applied Scientific Research, 3(8), 272282.

Taymur, İ., Türkçapar, M.H. (2012). Kişilik: Tanımı, sinıflaması ve değerlendirmesi. Psikiyatride Güncel Yaklaşımlar, 4(2), 154-177.
Thompson, J.A., Bunderson, J.S. (2003). Violations of principle: Ideological currency in the psychological contract. Academy of Management Review,28(4),571-586.

Tseng, H.Y. (2006). Communication factors which promote employee's job satisfaction in Taiwan high-tech industry: A personality traits study. Unpublished Master Thesis. University of Akron.

Tulubas, T., Celep, C. (2012). Effect of perceived procedural justice on faculty members' silence: The mediating role of trust in supervisor. Procedia-Social and Behavioral Sciences, 47, 1221-1231.

Tümkaya, S., Çelik, M., Aybek, B. (2011). Lise öğrencilerinde boyun eğici davranışlar, otomatik düşünceler, umutsuzluk ve yaşam doyumunun incelenmesi. Ç.Ü. Sosyal Bilimler Enstitüsü Dergisi, 20(2), 77-94.

Uyguç, N., Arbak, Y., Duygulu E., Çıraklar, N.H. (1998). İş ve yaşam doyumu arasındaki ilişkinin üç temel varsayım altında incelenmesi, Dokuz Eylül Üniversitesi İktisadi ve İdari Bilimler Fakültesi Dergisi, 13(11), 193-204.

Vakola, M., Bouradas, D. (2005). Antecedents and consequences of organizational silence: An empiricalinvestigation., Employee Relations, 27(5), 441-458.

VitalSmarts (2013). Eliminating Cultures of Silence. Position Paper. <www.vitalsmarts.com>. 